\title{
A Detailed Analysis of Daily, Seasonal and Yearly Performance Values of Photovoltaic Modules Using by a Simplified Method
}

\author{
Mehmet Azmi Aktacir ${ }^{1}$ (D), Erdal Yıldırım 2,* (D), Yusuf Işıker ${ }^{3}$ \\ 1,3Harran University, Mechanical Engineering Department, Şanlıurfa, Turkey \\ ${ }^{2}$ Harran University, Technical Sciences Vocational School, Şanlıurfa, Turkey
}

\begin{abstract}
The performance of panels for PV system design is determined according to the performance values in standard test conditions specified in the panel catalog, without knowing the performance under actual operating conditions. However, the operating performance of the PV panel depends on meteorological characteristics of place where the PV system is installed. Especially, if outside temperature values are above test conditions, the efficiency of the PV panel decreases and generation losses are observed. In this study, performance parameters of photovoltaic panel were calculated for four different PV panel technologies only by using their catalogue values like NOCT temperature (the cell temperature under conditions as solar radiation $800 \mathrm{~W} / \mathrm{m}^{2}$, surface temperature $20^{\circ} \mathrm{C}$, wind speed $1 \mathrm{~m} / \mathrm{s}$ and air mass 1.5), power-temperature coefficient etc. For this purpose, real working conditions were simulated using 3-year climate data for the meteorological conditions of Şanlıurfa, Turkey. In the end, PV panel efficiency, electricity generation values and performance ratios were calculated in accordance with the temperature. According to the results obtained, the PV panels' performance ratios decreased up to 0.75 during the summer months. The highest unit energy generation was achieved with thin film PV technology.
\end{abstract}

Keywords: performance ratio; PV panel efficiency; energy generation

\section{INTRODUCTION}

The most important component of photovoltaic (PV) systems is PV panels that generate electricity directly from the sun. Electricity generation from PV panels depends on panel material, solar radiation and other atmospheric variables such as surface air temperature and surface wind velocity that affect panel efficiency $[1,2,3]$. PV panels are produced according to various technologies including silicon material. In practice, Mono-silicon, Multi-silicon crystal types and Thin-film technology are the most preferred panel types [4]. High efficiency (HIT) panels, which have recently been produced as multi-junctions, are also being used. The most important parameter that affects the choice of PV panels is PV panel efficiency. This shows the rate at which solar energy on the PV panel surface turns into electrical energy. PV panel efficiencies are measured at standard test conditions (STC). However, although STC, defined as solar radiation $1000 \mathrm{~W} /$ $\mathrm{m}^{2}$, surface temperature $25^{\circ} \mathrm{C}$ and air mass (A.M.) 1.5 , are considered to be ideal conditions, they do not represent the actual field conditions in which the PV panel will operate [4]. The PV panels produced by different manufacturers can be easily compared in accordance with panel test efficien- cies measured according to the STC. In addition, PV panel manufacturers give Nominal Operation Cell Temperature (NOCT) conditions for panel performance values that are closer to actual conditions. NOCT conditions are defined as solar radiation $800 \mathrm{~W} / \mathrm{m}^{2}$, surface temperature $20^{\circ} \mathrm{C}$, wind speed $1 \mathrm{~m} / \mathrm{s}$ and air mass 1.5 . In order to simulate actual operating conditions of PV panels, the performance values obtained for the NOCT conditions are taken into account. When a module is operating in NOCT, "standard operating conditions" (SOC) are used [3].

One of the most important factors affecting the PV panel efficiency is outdoor air temperature. Although some of the solar energy on PV surface is converted into electricity, larger part is converted to heat, increasing the surface temperature $[5,6]$. Regarding this issue, there are various studies in the literature. There are many cooling methods investigations on PV, categorizing them according to heat transfer modes: convective cooling (hydro and aero-based cooling with or without extended surfaces), conductive cooling (phase change materials), and radiative cooling. Nanofluids have a significant enhancement of PVT systems performance as overall efficiency can reach $61.23 \%$ using MWCNT/water 
(0.075\% concentration). Aero-based cooling of PVs can achieve an enhancement in electrical performance by $~ 29 \%$ [7]. Photovoltaic (PV) panels can increase their efficiency and durability by using water-cooled systems. The results showed that decreased temperature provided by a cooling system and the use of the hot water so generated increases the efficiency of the panels by $30 \%$ compared to the system without cooling arrangements [8]. Attaching PCMs at the back of PV panel introduces external cooling power of PV due to the latent heat storage capacity of PCMs and achieves better system performance. [9] Using both paraffin wax and beeswax as a phase change material in PV-PCM system was tested in outdoor environment.With PCM, one-day experimental results show PV efficiency is enhanced from 6.1\%-6.5\% to $7.0 \%-7.8 \%$ [10].In an experimental study, it was observed that the increase of the PV module temperature decreased the efficiency [1]. In another study [5], the effects of environmental factors such as ambient temperature and solar radiation on the temperature of the PV panel and the output performance were investigated. It was shown that PV panel temperature had a very important role in output power generation. In a study of how photovoltaic (PV) module performance varies on continental scale [11], it has found that the strongest effect is seen in the dependence on irradiance and module temperature, which may range from $-20 \%$ to $+5 \%$ at different locations. A group of researchers have also shown that PV efficiency can be increased by passive and active cooling systems to reduce the PV surface temperature [6]. Similarly, there are studies examining the wind effect on PV power performance in literature as well. $[12,13]$. For example, in a study, the wind effect was investigated to rescue the PV surface temperature. It was found that increased wind speed enhanced the efficiency by 10 $12 \%$ [12]. There are identical studies that estimate the field performance of the PV system [4, 14]. A study [15] presented a reliable mathematical method for predicting energy production of grid-connected photovoltaic systems with different technologies commercially used in different regions of India. In another study [3], PV utility and PV power models that are existent in the literature were examined, depending on temperature. In addition, in a different study [16], the effect of increasing panel temperature on deposition of dust particles on PV surface was investigated. In general, it was stated that increasing the temperature of the PV modules reduces the energy conversion efficiency of these modules. However, in outdoor air conditions with a higher PV surface temperature difference, it was found that there was a higher output due to the deposition of less dust particles than at lower temperature differences.

The performance of solar panels is reduced on hot days when the outdoor air temperature is higher than STC test temperature $\left(25^{\circ} \mathrm{C}\right)$. The temperature-power coefficient is used to determine the effect of operating temperature on PV performance [4]. The PV panels with low temperature-power coefficient are less affected by temperature.
Performance ratio (PR) is variable to calculate efficiency of a PV panel. PR is the ratio of actual output and theoretical output energy. The performance ratio is one of the most important parameters for evaluating the efficiency of a PV panel $[15,4,17$, and 18]. PR is largely independent from the orientation of a PV system and incident solar irradiation on the PV plant. For this reason, the performance ratio can be used to compare PV system at different locations all over the world [17]. Generally, PR is used as a fruitful way of quantifying the overall effect of losses due to PV module temperature, spectrum, module mismatch and other losses such as optical reflection, soiling and downtime failures [4]. Another measurement parameter describing the performance of PV-systems is the Specific Yield (SY). It measures the production per installed power and is a very good way of measuring the performance of PV systems since the production is proportional to the potential earnings of the system while the installed power reflects the cost of the system [18].

PV panel performance depends on parameters such as meteorological value, panel technology as explained above. In PV system design, when panels are selected according to standard test conditions, PV system design may be faulty/ inadequate. In this study, it is aimed to easily determine the performance parameters of photovoltaic panels in real working conditions. For this purpose, a simple method has been proposed to calculate the daily, monthly and yearly performance parameters of PV panel. In this study, 4 different PV panel technologies were employed, and 3-year outdoor temperature and solar radiation values in meteorological conditions of Şanlıurfa, Turkey were used. Besides, Nominal Operation Cell Temperature (NOCT) conditions and power-temperature coefficient easily found in the panel catalogues were used in calculation of panel performance parameters. Thus, the PV system was simulated for one year and performance values were determined accordingly.

In this study, while designing PV systems, measured real values were used instead of standard test conditions. By selecting the prominent PV technologies, their performances were calculated using real operating conditions. Thus, an efficiency calculation method consists of Specific Yield and Performance Ratio was proposed to determine the daily, monthly, and annual performances of selected PV technologies with locational data.

\section{MATERIALS AND METHODS}

\section{1. Şanlıurfa's Climate}

In this study, the performance of PV panels will be examined in the meteorological conditions of Şanllurfa which has a hot climate. Şanliurfa is located in the southeast Anatolia region of Turkey and has a continental climate with a high solar energy potential. The global solar radiation potential map of Turkey is given in Fig. 1 [19, 20]. As can be seen from the figure, the value of global solar radiation in the north of Turkey is about $1400 \mathrm{kWh} / \mathrm{m}^{2}$ per year while these values are in the range of $2000 \mathrm{kWh} / \mathrm{m}^{2}$ per year in the south. This 
shows that Turkey's southern region has a significant potential for solar energy applications.

\subsection{Meteorological Data}

In this study, data from the meteorological station of Harran University called GAPYENEV center in Şanlıurfa was used. These data include the global radiation on horizontal surface, sunshine durations, and outside air temperatures measured over a period of 10 minutes between the years 2014 and 2016. Monthly mean values of all meteorological data and average daily variation for each month were also calculated.

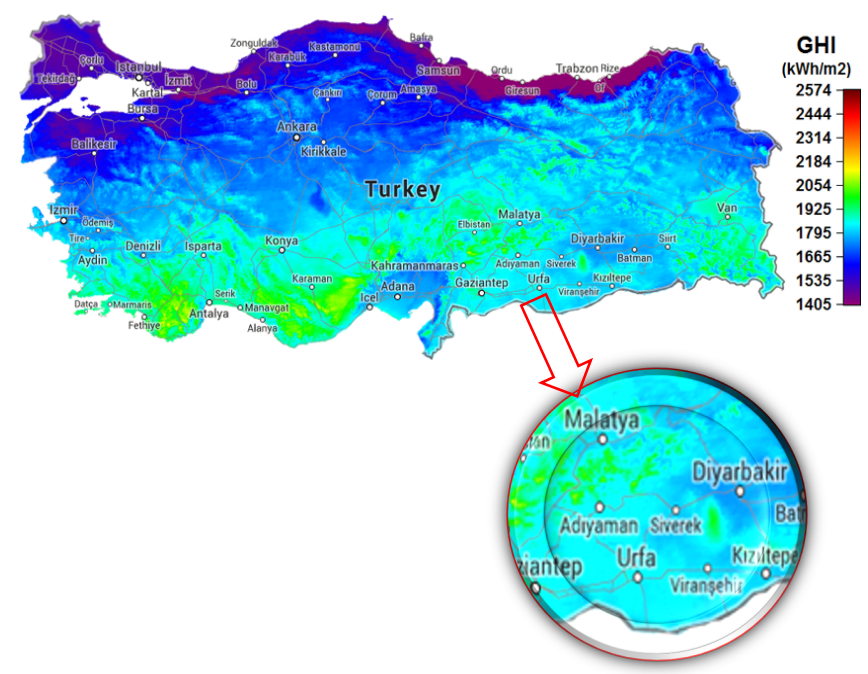

Figure 1. Annual global solar radiation potential map of Turkey [21]

\subsection{Photovoltaic Panel Technologies}

Four different PV technologies were used in this study. These are HIT, Mono-silicon, Multi-silicon and Thin-film $(\mathrm{CdTe})$, respectively. The characteristic values of these panels are presented in Table1 [22,23,24,25]

\subsection{Solar radiation analyses}

PV panels were investigated in two different positions, horizontal and inclined at $30^{\circ}$ to the south. The isotropic diffuse model, given in the study by Schwingshacklet al. [13], is used to calculate the total solar radiation values on the inclined surface. With this method, the total solar radiation on the inclined surface is calculated as below,

$$
I_{T}=I_{b} R_{b}+I_{d}\left(\frac{1+\cos \beta}{2}\right)+I \rho_{g}\left(\frac{1-\cos \beta}{2}\right)
$$

On the right side of the equation are direct, diffuse and reflected elements of total solar radiation, respectively. $I_{b}$ and $I_{d}$ represent the direct and diffuse radiation on the horizontal surface. $R_{b}$ is the surface slope. is the ratio of direct radiation on tilted surface to radiation on horizontal surface at any time and is calculated as,

$$
R_{b}=\frac{\operatorname{Cos} \theta}{\operatorname{Cos} \theta_{z}}
$$

The incident angle $\theta$ of solar radiation is the angle between direct radiation and the surface normal. The relation between $\theta$ and the other angles is as below,

$$
\begin{aligned}
& \cos (\theta)=\sin (\delta) \cdot \sin (\varphi) \cdot \cos (\beta)-\sin (\delta) \cdot \cos (\varphi) \cdot \sin (\beta) \cdot \cos (\gamma) \\
& +\cos (\delta) \cdot \cos (\varphi) \cdot \cos (\beta) \cdot \cos (\omega)+\cos (\delta) \cdot \sin (\varphi) \cdot \sin (\beta) \cdot \cos (\gamma) \cdot \cos (\omega) \\
& +\cos (\delta) \cdot \sin (\beta) \cdot \sin (\gamma) \cdot \sin (\omega)
\end{aligned}
$$

For horizontal surfaces, the angles of incidence are equal to the zenith angle $\theta_{z}$. In this case, the slope $\beta=0$ and the equation 3 becomes as follows,

$$
\operatorname{Cos}\left(\theta_{z}\right)=\cos (\varphi) \cdot \cos (\delta) \cdot \cos (\omega)+\sin \varphi \cdot \sin (\delta)
$$

$\phi$ and $\omega$ are the latitude and hour angle respectively. $\gamma$ is the azimuth angle and the value for south facing surfaces is zero. $\delta$, declination angle is calculated using the formula given as below,

$$
\delta=23,45 \sin \left(360 \frac{284+n}{365}\right)
$$

\subsection{Determination of Panel performance parameters}

The surface temperature $\left(T_{\text {panel }}\right)$ of the photovoltaic panel is critical parameter, governing the efficiency performance of photovoltaic panel [26]. The method used in this study for the estimation of PV performance can be expressed as a function of solar radiation and panel temperature. In literature, there a lot of photovoltaic module temperature models [27]. For the present study it has used the model described in [28]. In another study [15], for validation of this model actual field output of PV plants were compared with the predicted value. It has been determined that the model performs satisfactorily.

The surface temperature $\left(T_{\text {panel }}\right)$ of the photovoltaic panel is calculated by Equation $6[15,18,28]$ according to the outside air temperature $\left(T_{\text {air }}\right)$. NOCT represents nominal operating conditions of the panel. Standard NOCT values for all panels are given in Table $1\left(20^{\circ} \mathrm{C}\right.$ and $\left.800 \mathrm{~W} / \mathrm{m}^{2}\right)$. In Equation 6, $T_{N O C T}$ and $I$ represent panel temperature at nominal operating conditions, and solar radiation value, respectively.

Table1. Typical panels of the different technologies available

\begin{tabular}{|c|c|c|c|c|}
\hline Technology & HIT & Thin-film & Mono-silicon & Multi-silicon \\
\hline Manufacturer & Panasonic & First solar & Solar world & Yingli solar \\
\hline PV Efficiency & $\% 19.7$ & $\% 14.6$ & $\% 17.89$ & $\% 16$ \\
\hline NOCT & $44^{\circ} \mathrm{C}$ & $45^{\circ} \mathrm{C}$ & $46^{\circ} \mathrm{C}$ & $46+/-2^{\circ} \mathrm{C}$ \\
\hline Temperature-Power Coefficient & $-0.29 \% /{ }^{\circ} \mathrm{C}$ & $-0.34 \% /{ }^{\circ} \mathrm{C}$ & $-0.39 \% /{ }^{\circ} \mathrm{C}$ & $-0.42 \% /{ }^{\circ} \mathrm{C}$ \\
\hline Panel Surface Area for $1 \mathrm{kWp}$ & $4.70 \mathrm{~m}^{2}$ & $6.86 \mathrm{~m}^{2}$ & $4.87 \mathrm{~m}^{2}$ & $5.62 \mathrm{~m}^{2}$ \\
\hline NOCT Conditions & \multicolumn{4}{|c}{$20^{\circ} \mathrm{C}, 800 \mathrm{~W} / \mathrm{m}^{2}, 1.5 \mathrm{~A} . \mathrm{M} .11 \mathrm{~m} / \mathrm{s}$ wind speed } \\
\hline STC Conditions & $25^{\circ} \mathrm{C}, 1000 \mathrm{~W} / \mathrm{m}^{2}, 1.5$ A.M. \\
\hline
\end{tabular}




$$
T_{\text {panel }}=T_{\text {air }}+\frac{T_{N O C T}-20}{800}
$$

The efficiency of PV panel at different surface temperatures $\left(\eta_{\text {temp_panel }}\right)$ is calculated by Equation 7 . Here, $\eta_{\text {panel }}$ represents the panel efficiency for the standard test conditions given in the PV panel catalog. While $\mathrm{T}_{\text {STC }}$ is the operating temperature for standard test conditions, $\mathrm{K}_{\mathrm{pc}}$ is the temperature power coefficient given in catalogs.

$$
\eta_{\text {temp_panel }}=\eta_{\text {panel }}\left(1-\left(T_{\text {panel }}-T_{S T C}\right) K_{p c}\right.
$$

For the unit area, the theoretical electric energy $\left(P_{\text {electric } \_ \text {teo- }}\right.$ ric) generated from the PV panels is calculated by Equation 8. The electricity generation depending on the temperature $\left(P_{\text {elect_temp }}\right)$ is calculated by Equation 9 . Equations 8 and 9 are shown as the standard test efficiency $\left(\eta_{\text {panel }}\right)$ given in PV panel's catalogue and the temperature dependent PV panel efficiency $\left(\eta_{\text {temp_panel }}\right)$, respectively. There is a generation loss due to dust, electricity and inverter loss in PV systems. In this study, the total loss $\left(P_{\text {loss }}\right)$, including dust, electricity and inverter losses, was accepted as 10\% [18].

$$
\begin{aligned}
& P_{\text {elekt_teoric }}=I \eta_{\text {panel }} \\
& P_{\text {elekt_temp }}=I \eta_{\text {panel } l_{\text {temp }}}\left(1-P_{\text {loss }}\right)
\end{aligned}
$$

The temperature dependent generation loss/gain from PV panels is determined by proportioning the electricity energy $\left(P_{\text {elekt_temp }}\right)$ generated from PV panels, depending outside air temperature to the electricity ( $P_{\text {elekt_teoric }}$ ) generated under standard test conditions (Equation 10). This is the performance ratio (PR) of the PV system $[15,4,17,18]$. PR is stated as percent and describes the relationship between actual and theoretical energy outputs of a PV system.

$$
P R=\frac{P_{\text {elekt_temp }}}{P_{\text {elekt_teoric }}}
$$

Another performance indicator of PV system is the total output per $1 \mathrm{kWp}$ installed power, called as Specific Yield (SY). In this study, SY value is calculated by Equation 11 . The unit of SY is kWh/kWp. A is the surface area of the PV panel required for $1 \mathrm{kWp}$ installed power.

$$
S Y=P_{\text {elekt_temp }} A
$$

\section{DISCUSSION AND RESULTS}

The monthly mean solar radiation, sunshine duration and outdoor air temperature values of Şanlıurfa, obtained from GAPYENEV meteorological station, are given in Table 2. CH-1 model pyrheliometer mounted on Kipp \& Zonen 2AP solar tracking system with $9.76 \times 10^{-6} \mathrm{Wm}^{-2}$ sensitivity was used in direct solar radiation measurement. CMP11 model pyranometer with $8.89 \times 10^{-6} \mathrm{~V} / \mathrm{Wm}^{-2}$ sensitivity was used in diffuse radiation measurement. As can be seen from the table, Şanlıurfa's annual global radiation value is $1828 \mathrm{kWh} / \mathrm{m}^{2}$ per year, sunshine duration is 3434 hours and annual average temperature is $18.8^{\circ} \mathrm{C}$. According to monthly average values, maximum values were reached in July. In July, the average outside temperature is $32.2^{\circ} \mathrm{C}$, global solar radiation is $244 \mathrm{kWh} / \mathrm{m}^{2}$ per year and sunshine duration is 421 hours. Outside temperature values fell below $10^{\circ} \mathrm{C}$ in December, January and February.

Table 2. Monthly average solar radiation, sun duration and outdoor air temperature of Şanlıurfa

\begin{tabular}{|c|c|c|c|}
\hline & $\begin{array}{c}\text { Average Outdoor } \\
\text { Air Temperature } \\
\left({ }^{\circ} \mathrm{C}\right)\end{array}$ & $\begin{array}{c}\text { Average Global Solar } \\
\text { Radiation } \\
\left(\mathrm{kWh} / \mathrm{m}^{2} \text { year }\right)\end{array}$ & $\begin{array}{c}\text { Average Sun } \\
\text { Duration (h) }\end{array}$ \\
\hline January & 5.2 & 68 & 188 \\
\hline February & 9.4 & 83 & 237 \\
\hline March & 11.8 & 136 & 214 \\
\hline April & 16.9 & 185 & 278 \\
\hline May & 22.3 & 215 & 325 \\
\hline June & 28.0 & 234 & 411 \\
\hline July & 32.2 & 244 & 421 \\
\hline August & 31.2 & 217 & 392 \\
\hline September & 26.5 & 172 & 339 \\
\hline October & 20.5 & 117 & 280 \\
\hline November & 12.8 & 90 & 243 \\
\hline December & 8.9 & 66 & 126 \\
\hline Yearly & 18.8 & 1828 & 3454 \\
\hline
\end{tabular}

The mean hourly solar radiation of Şanlıurfa on horizontal and south facing areas with a tilt of $30^{\circ}$ is given in Figure 2. As can be seen from the figure, the solar radiation on horizontal surface varies according to month and reach maximum values in summer $\left(946 \mathrm{~W} / \mathrm{m}^{2}\right.$ at 12.00 in July). The solar radiation reaches maximum values in the months when solar rays strike directly to the surface of PV facing south with $30^{\circ}$. In September, $1000 \mathrm{~W} / \mathrm{m}^{2}$ values are seen between 9.00 and 14.00 hours (Figure 2).
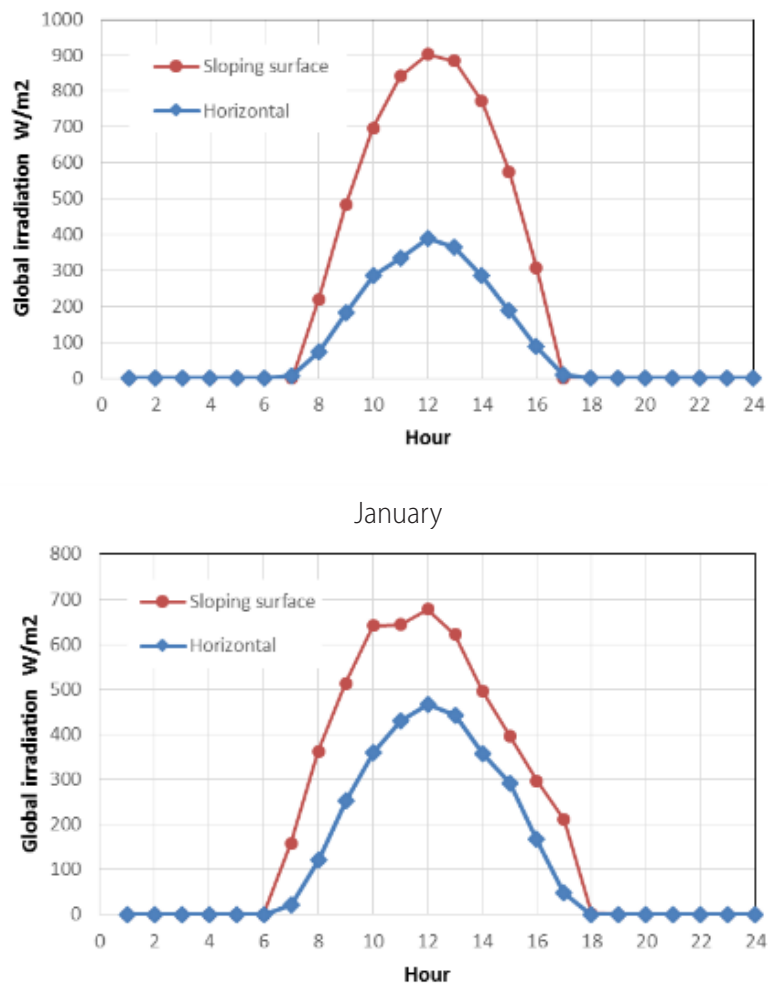

February 

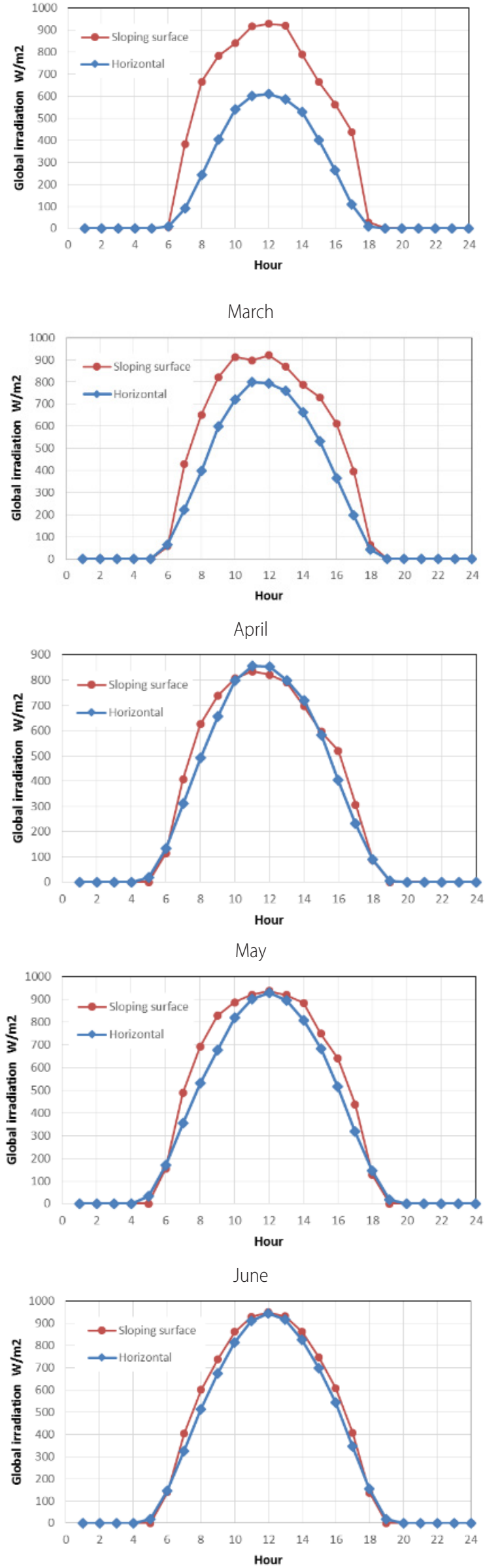

July

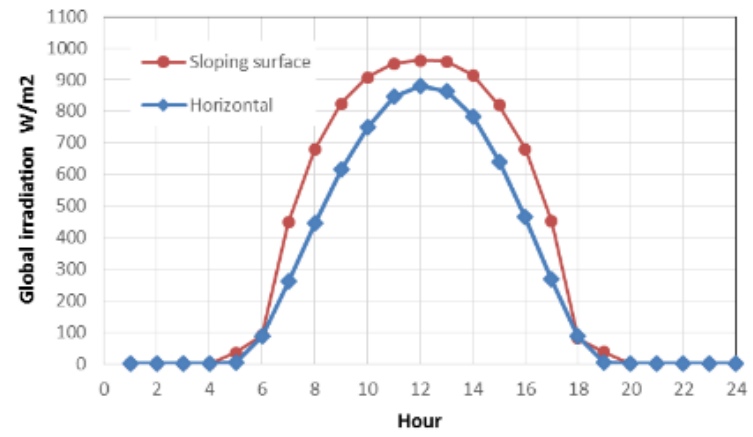

August

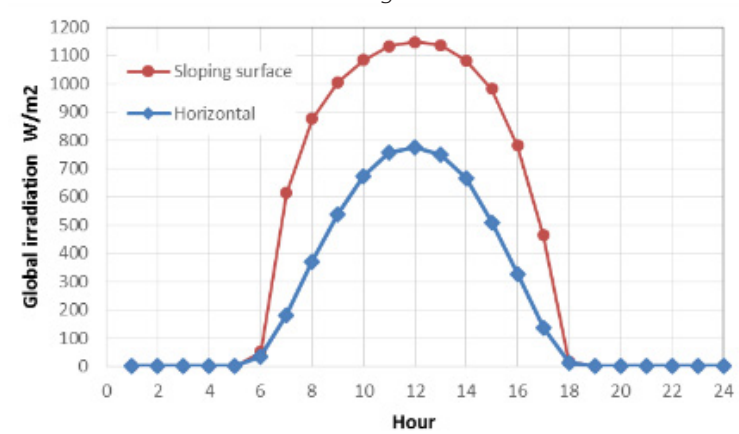

September

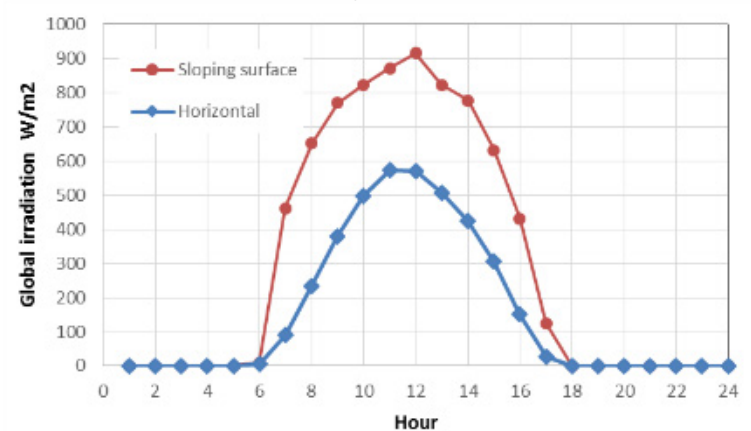

October

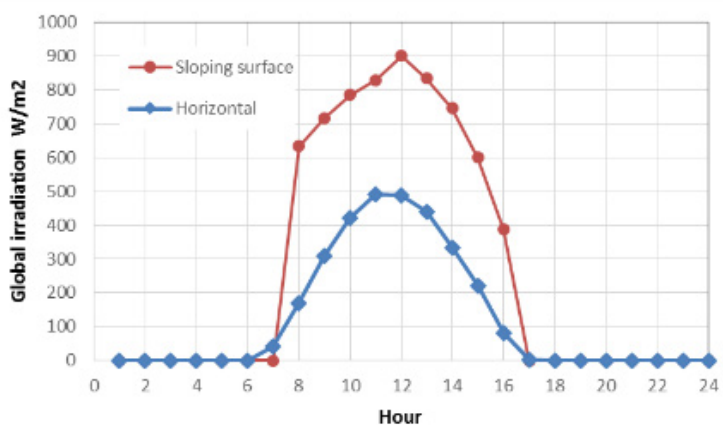

November

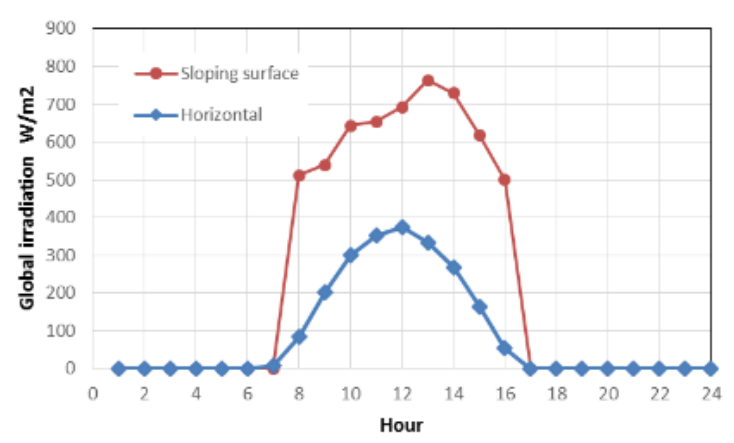

December

Figure 2. Monthly average distribution $(\mathrm{H})$ of solar radiation on horizontal and south facing surface with a $30^{\circ}$ tilt in Şanlıurfa 

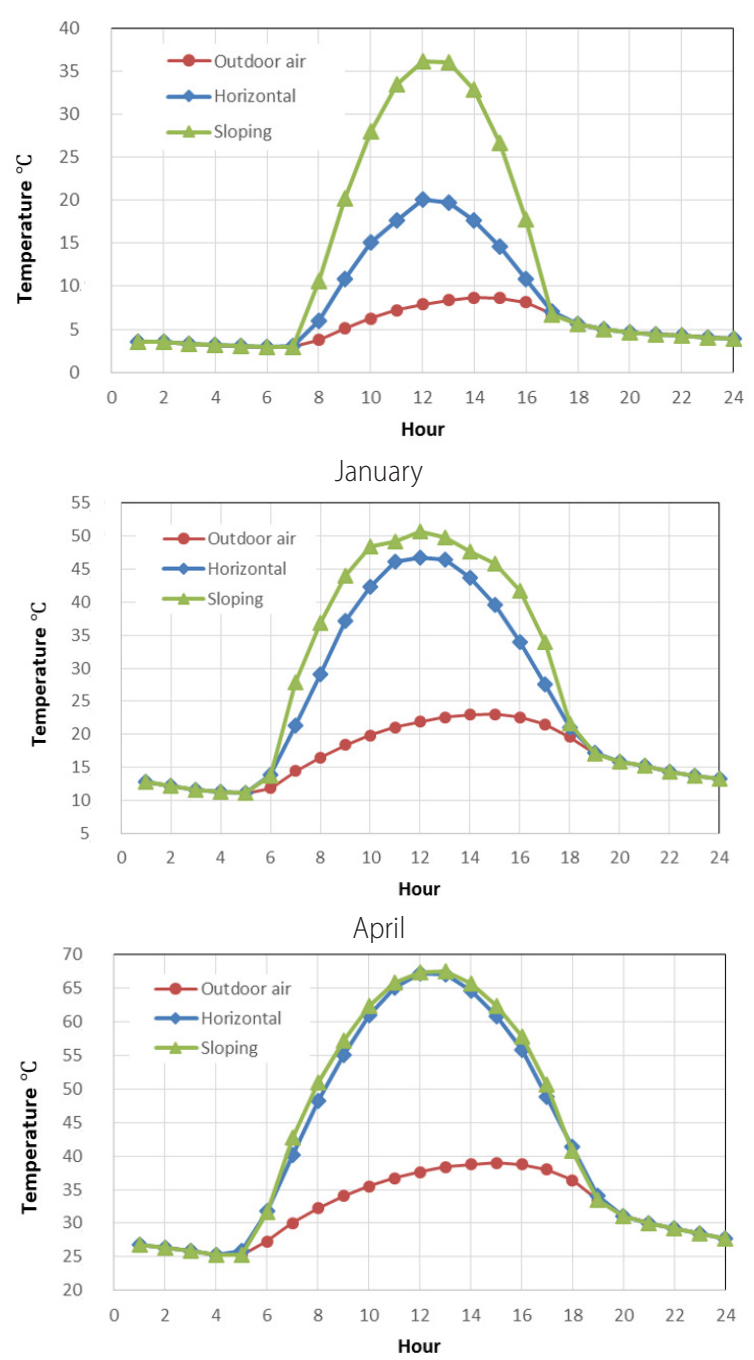

July

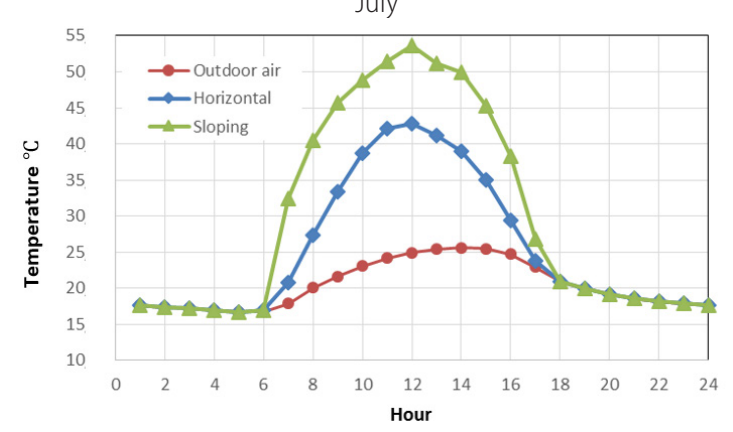

October

Figure 3. Monthly average distribution $(\mathrm{H})$ of outdoor air temperature and surface temperature of PV panel mounted horizontal and $30^{\circ}$ tilt south facing surfaces in Şanlıurfa

Similarly, Figure 3 shows the PV panel surface temperature distribution for Şanlıurfa in January, April, July and October calculated according to the hourly average outdoor temperature. These graphs are calculated for thin-film technology panels. As can be seen from the figure, the outside temperature is maximum $9{ }^{\circ} \mathrm{C}$ in temperature distribution graph obtained for January, while the surface temperature of horizontal PV panel is $20^{\circ} \mathrm{C}$ and it is $36^{\circ} \mathrm{C}$ for the south facing panel with $30^{\circ}$ slope. A similar profile was obtained in October. The outside air temperature is maximum $25^{\circ} \mathrm{C}$ while the surface temperature of horizontal PV panel is $43^{\circ} \mathrm{C}$ and the surface temperature of south facing PV panel (with $30^{\circ}$ slope) reaches $54^{\circ} \mathrm{C}$. The temperature distribution profiles
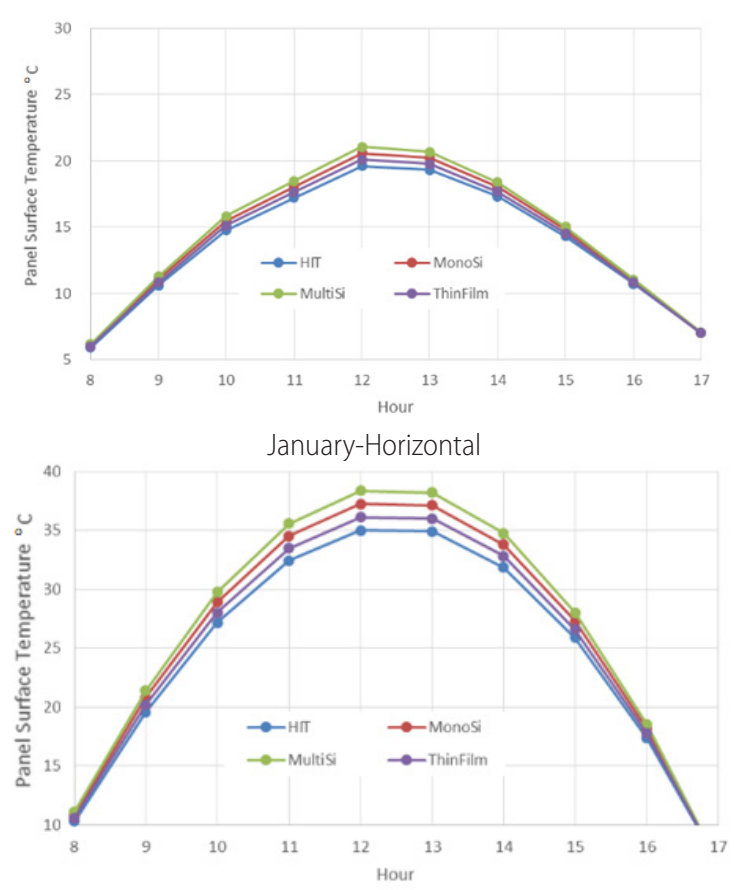

January-Sloping

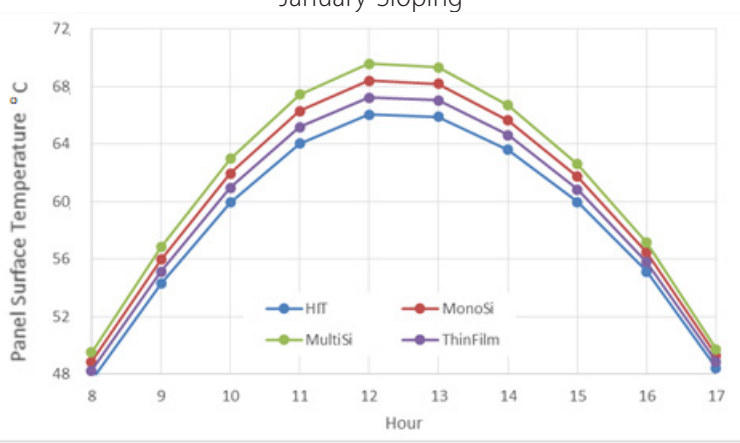

July-Horizontal

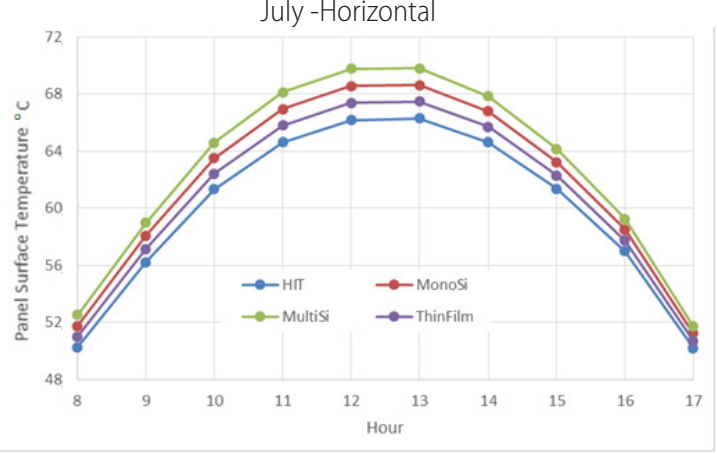

July-Sloping

Figure 4. For different PV technologies, surface temperature distribution of PV Panels mounted as Horizontal and Sloping surfaces

in July and April are similar. In July, the surface temperatures of horizontal and south facing (with $30^{\circ}$ slope) were very close to each other and the maximum was $68^{\circ} \mathrm{C}$. According to the annual data, the maximum PV panel surface temperature for Thin-film technology reaches to $68^{\circ} \mathrm{C}$.

On the other hand, Figure 4 shows the surface temperature distributions of horizontal and south facing PV panels for January and July for 4 different PV technologies examined in this study. The highest temperature value in all graphs was observed in Multi-silicon technology. This was followed by Mono-silicon, Thin-film and HIT PV technologies, respectively. In January, the surface temperature of the horizontal 

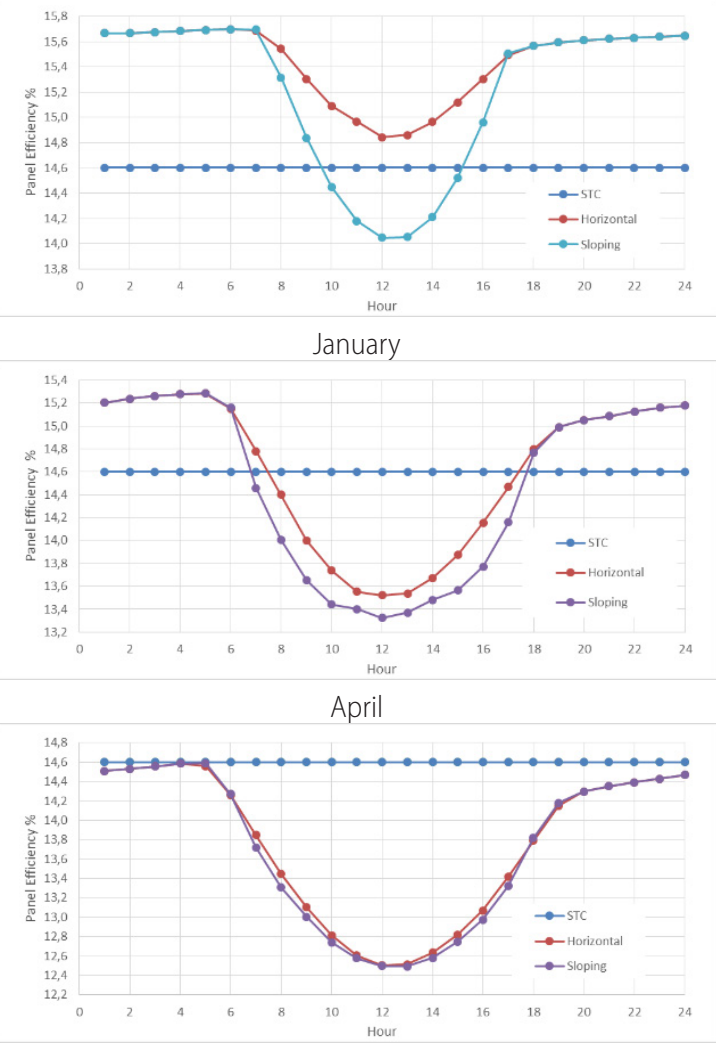

July

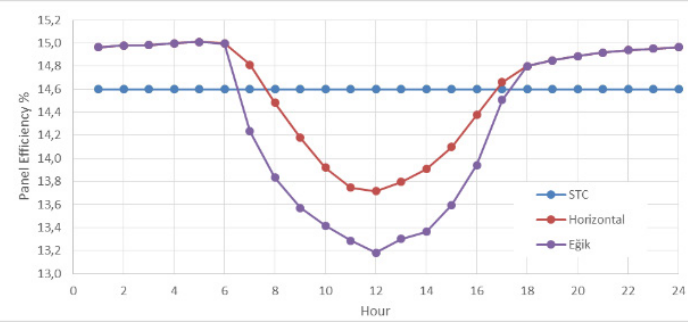

October

Figure 5. PV panel efficiency distribution (H) of Thin-film PV panels mounted horizontal and sloping surface in January, April, July and October in Şanlıurfa

PV panels is $20^{\circ} \mathrm{C}$. However, in the case of tilted PV panels, it increased to $35-40^{\circ} \mathrm{C}$ depending on the technology employed. In July, the temperature profiles are very close and similar. In this month, the highest temperature value was observed at $70^{\circ} \mathrm{C}$ for Multi-silicon technology. This is followed by Mono-silicon $\left(68^{\circ} \mathrm{C}\right)$, Thin-film $\left(67^{\circ} \mathrm{C}\right)$ and HIT PV $\left(66^{\circ} \mathrm{C}\right)$, respectively.

Figure 5 shows the hourly distribution of panel efficiency for horizontal and sloping conditions of Thin-film PV type, calculated according to hourly average outdoor temperature values in Şanlıurfa in January, April, July and October. In Figure 5a, it is seen that the efficiency of the PV panel is $14.6 \%$ at standard test conditions. The PV panel efficiencies vary depending on the panel surface temperature for horizontal or southward surfaces. In case of the PV panel laid horizontally in Figure 5a, the panel efficiency is higher than the PV panel efficiency (14.6\%) in the standard test conditions since the outside air temperature and therefore the panel surface temperatures are low in January. If the panels placed at a slope of $30^{\circ}$ to the south, the PV panel efficiency becomes similarly high except for 10.00-15.00 hours. As seen in Figu-
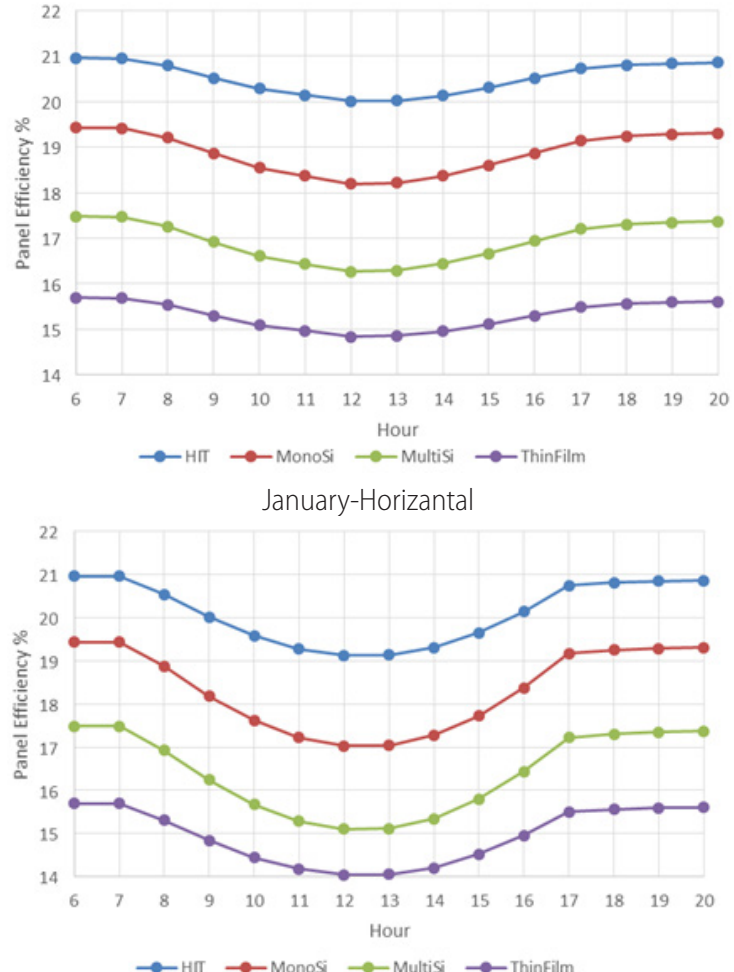

January-Sloping Surface

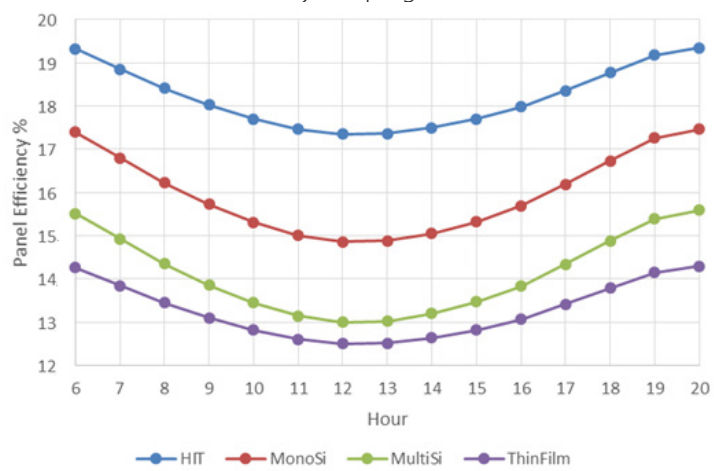

July - Horizantal

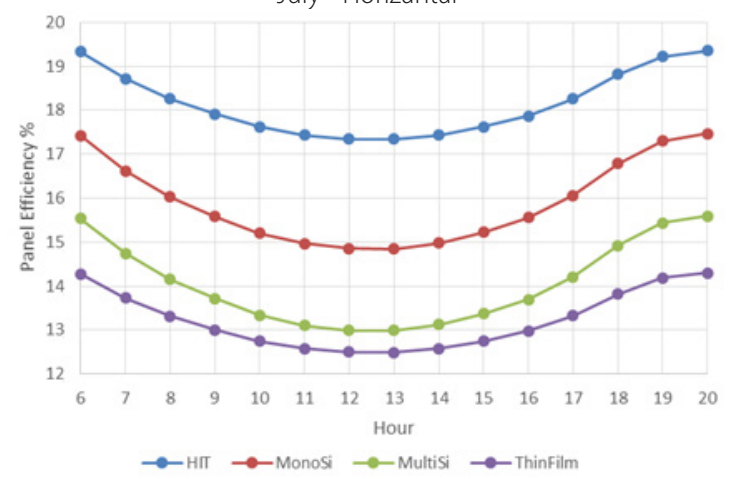

July- Sloping Surface

Figure 6. PV panel efficiency distributions according to Different PV Technologies

re $5 \mathrm{~b}$ and $\mathrm{d}$, if the PV panel is placed horizontally and oriented with a $30^{\circ}$ slope to the south, the profiles of the panel efficiencies obtained for April and October become similar and lower than the PV panel efficiency (14.6\%) in standard test conditions except for sunrise and sunset times. On the other hand, in Fig. 5c, the panel efficiencies obtained for July are lower than the PV panel efficiencies for all hours under standard test conditions and it is $12.5 \%$ at 12.00 . Panel effi- 
ciencies vary between 12.5 and 14.6 during the day.

Figure 6 shows the daily distribution of PV panels efficiencies placed horizontally and sloping $30^{\circ}$ to the south in January and July for 4 different PV technologies examined in this study. As can be seen in the figure, the highest panel efficiency in January and July was observed for HIT PV technology. This is followed by Mono-silicon, Multi-silicon and Thin-film technologies, respectively. Horizontal panels' efficiencies were less affected in January than in July with respect to those of sloped panels.

Table 3 shows the performance ratio obtained by proportioning the electric energy generated from the PV panels depending on the outside air temperature to the electric energy generated under standard test conditions. The values of PR below 1.0 are regarded to be losses according to the temperature dependent theoretical production at standard test conditions. On the other hand, the values above this level indicate the production gain. For example, if $\mathrm{PR}=1.03$, it indicates that production is $3 \%$ higher than the theoretical production, whereas it is $11 \%$ lower if $\mathrm{PR}=0.89$. As can be seen from Table 3, in January, the PR value of HIT PV panels is 1.03 and the electricity production based on the outside air temperature is $3 \%$ higher than the theoretical electri- city generated under standard test conditions. However, in September, the PR value of Multi-silicon PV panels is 0.75 , which means $25 \%$ less energy than standard test conditions. Annual production losses of PV panels due to temperature effect were observed in all PV technologies examined. The lowest annual performance values were found to be in the Multi-silicon PV technology, calculated to be 0.94 and 0.82 , respectively, according to the horizontal and inclined installation of the PV panel. On the other hand, the highest annual performance values were found to be 0.96 and 0.85 , respectively, for horizontal and inclined installations of the HIT PV panel technology.

Likewise, Table 4 shows monthly and annual production quantities (SY) (kWh/kWp) per $1 \mathrm{kWp}$ installed power according to the PV panel technologies. In the case of the PV system which is installed horizontally, the lowest SY value for all PV technologies was observed in December and January while the highest SY value was observed in July. Unit production values are found to be the highest for Thin-film PV technology and the lowest for Mono-silicon PV technology. The highest unit production values were calculated to be $1703 \mathrm{kWh} / \mathrm{kWp}$ per year for Thin-film PV technology whereas the lowest was for Mono-silicon with $1468 \mathrm{kWh} /$ $\mathrm{kWp}$.

Table 3. Monthly and yearly PV performance ratios (PR) for PV panel technologies

\begin{tabular}{|c|c|c|c|c|c|c|c|c|}
\hline \multirow{2}{*}{ Months } & \multicolumn{2}{|c|}{ HIT } & \multicolumn{2}{c|}{ Mono-Silicon } & \multicolumn{2}{c|}{ Multi-Silicon } & \multicolumn{2}{c|}{ Thin-film } \\
\cline { 2 - 11 } & Horizontal & $\begin{array}{c}\text { Sloping } \\
\text { Surface }\end{array}$ & Horizontal & $\begin{array}{l}\text { Sloping } \\
\text { Surface }\end{array}$ & Horizontal & $\begin{array}{c}\text { Sloping } \\
\text { Surface }\end{array}$ & Horizontal & $\begin{array}{c}\text { Sloping } \\
\text { Surface }\end{array}$ \\
\hline January & 0.96 & 0.85 & 0.94 & 0.83 & 0.94 & 0.82 & 0.95 & 0.84 \\
\hline February & 1.03 & 0.89 & 1.03 & 0.88 & 1.03 & 0.87 & 0.93 & 0.88 \\
\hline March & 1.01 & 0.89 & 1.01 & 0.89 & 1.00 & 0.88 & 1.01 & 0.89 \\
\hline April & 0.99 & 0.87 & 0.98 & 0.85 & 0.97 & 0.84 & 0.98 & 0.86 \\
\hline May & 0.96 & 0.85 & 0.94 & 0.83 & 0.93 & 0.82 & 0.95 & 0.84 \\
\hline June & 0.94 & 0.84 & 0.91 & 0.82 & 0.90 & 0.81 & 0.92 & 0.83 \\
\hline July & 0.92 & 0.82 & 0.88 & 0.79 & 0.87 & 0.77 & 0.90 & 0.80 \\
\hline August & 0.90 & 0.81 & 0.86 & 0.77 & 0.85 & 0.76 & 0.88 & 0.79 \\
\hline September & 0.91 & 0.81 & 0.87 & 0.77 & 0.86 & 0.76 & 0.89 & 0.79 \\
\hline October & 0.93 & 0.81 & 0.90 & 0.77 & 0.89 & 0.75 & 0.92 & 0.79 \\
\hline November & 0.96 & 0.85 & 0.95 & 0.82 & 0.94 & 0.81 & 0.96 & 0.83 \\
\hline December & 0.99 & 0.86 & 0.99 & 0.85 & 0.98 & 0.84 & 0.99 & 0.86 \\
\hline Yearly & 1.01 & 0.88 & 1.02 & 0.87 & 1.02 & 0.87 & 1.01 & 0.88 \\
\hline
\end{tabular}

Table 4. Monthly and yearly Specific Yield (SY) for PV panel technologies (kWh/kWp)

\begin{tabular}{|c|c|c|c|c|c|c|c|c|}
\hline \multirow{2}{*}{ Months } & \multicolumn{3}{|c|}{ HIT } & \multicolumn{2}{|c|}{ Mono-Silicon } & \multicolumn{2}{c|}{ Multi-Silicon } & \multicolumn{2}{c|}{ Thin-film } \\
\cline { 2 - 11 } & Horizontal & $\begin{array}{c}\text { Sloping } \\
\text { Surface }\end{array}$ & Horizontal & $\begin{array}{c}\text { Sloping } \\
\text { Surface }\end{array}$ & Horizontal & $\begin{array}{c}\text { Sloping } \\
\text { Surface }\end{array}$ & Horizontal & $\begin{array}{c}\text { Sloping } \\
\text { Surface }\end{array}$ \\
\hline January & 65 & 145 & 62 & 135 & 64 & 138 & 63 & 156 \\
\hline February & 77 & 116 & 73 & 109 & 75 & 112 & 84 & 125 \\
\hline March & 125 & 197 & 116 & 182 & 119 & 186 & 134 & 212 \\
\hline April & 164 & 193 & 151 & 176 & 154 & 180 & 176 & 206 \\
\hline May & 187 & 178 & 171 & 162 & 174 & 166 & 199 & 190 \\
\hline June & 199 & 198 & 180 & 178 & 183 & 181 & 211 & 209 \\
\hline July & 204 & 194 & 183 & 174 & 186 & 176 & 216 & 205 \\
\hline August & 183 & 206 & 165 & 185 & 168 & 187 & 194 & 217 \\
\hline September & 148 & 233 & 135 & 209 & 138 & 211 & 158 & 246 \\
\hline October & 104 & 177 & 97 & 162 & 99 & 165 & 112 & 189 \\
\hline November & 83 & 155 & 77 & 142 & 80 & 146 & 89 & 165 \\
\hline December & 62 & 144 & 59 & 133 & 61 & 137 & 67 & 154 \\
\hline Yearly & 1601 & 2135 & 1468 & 1947 & 1500 & 1985 & 1703 & 2275 \\
\hline
\end{tabular}


On the other hand, in case of inclined PV panels, the lowest SY value for all PV technologies was observed in February while the highest SY value was observed in September. Monthly and yearly unit production values were highest in Thin-film PV technology and lowest in Mono-silicon PV technology. The highest unit production value was obtained in Thin-film PV technology with $2275 \mathrm{kWh} / \mathrm{kWp}$ per year whereas the lowest was in Mono-silicon PV technology with 1947 kWh/kWp.

\section{CONCLUSION}

In this study, PV panel performance values in detail were examined in meteorological conditions of Şanlıurfa. In the simulation, 4 different PV panel technologies, which are Multi-silicon, Mono-silicon, Thin-film and HIT PV technologies, and 3year outdoor temperature and solar radiation values of Şanlıurfa province were used. In the present study, the field performances of PV systems could be easily found by calculating the PV panel efficiency in accordance with the temperature.

According to the results obtained, it was observed that panel surface temperature increased due to an increase in outdoor air temperature. But, the increase in surface temperature of the panel decreased the efficiency owing to the temperature power coefficient of the panel. Efficiency losses were least observed in the months when the outdoor air temperature was low. However, the efficiency losses were particularly noticeable in summer months. In these months, PV panels' performance ratios decreased up to 0.75 .

Moreover, in the case of inclined PV panels, the lowest unit production value in all PV technologies was observed in February while the highest was in September. On the other hand, for horizontally installed PV panels, the lowest production was reached in December and January, and the highest production was observed in July. Among the PV technologies examined, the best unit production quantity was obtained in Thin-film technology whereas the lowest unit production values were obtained in Mono-silicon PV technology.

\section{Nomenclature}

$I_{T}$-Total Radiation on a tilted surface [ $\left.W \mathrm{~m}-2\right]$

$I_{b}$-Direct solar radiation on a horizontal surface [W $\left.\mathrm{m}-2\right]$

$I_{d}$-Diffuse solar radiation on a horizontal surface [W $\left.\mathrm{m}-2\right]$

$R_{b}$-Geometric factor

$I$-Hourly solar radiation on a horizontal surface [ $W \mathrm{~m}-2]$

$\eta$-Day of the year

\section{Greek symbols}

\section{$\beta$-Slope $\left[{ }^{\circ}\right]$}

$\gamma$-Surface azimuth angle $\left[^{\circ}\right]$

$\delta$-Declination, $\left[^{\circ}\right]$
$\eta$-Efficiency [\%]

$\theta$-Angle of incidence $\left[^{\circ}\right]$

$\theta_{z}$-Zenith angle $\left[^{\circ}\right]$

$\rho_{g}$-Ground reflectance

$\phi$-Latitude $\left[^{\circ}\right]$

$\omega$-Hour angle $\left[^{\circ}\right]$

\section{REFERENCES}

[1] Gedik, E. (2016). Experimental investigation of module temperature effect on photovoltaic panels' efficiency, Journal of Polytechnic, 19 (4): 569-576.

[2] Jerez, S., Tobin, I., Vautard, R., Montávez, J. P., López-Romero, J. M., Thais, F., ... , Nikulin, G. (2015). The impact of climate change on photovoltaic power generation in Europe. Nature communications, 6(1), 1-8.

[3] Skoplaki, E., Palyvos, J. A. (2009). On the temperature dependence of photovoltaic module electrical performance: A review of efficiency/power correlations. Solar energy, 83(5), 614-624.

[4] Makrides, G. et al. (2012). Performance of Photovoltaics Under Actual Operating Conditions, Third Generation Photovoltaics. Dr. Vasilis Fthenakis (Ed.), Intechopen.

[5] Razak, A., Irwan, Y. M., Leow, W. Z., Irwanto, M., Safwati, I., Zhafarina, M. (2016). Investigation of the effect temperature on photovoltaic (PV) panel output performance. International Journal on Advanced Science, Engineering and Information Technology, 6(5): 682-688.

[6] Hasanuzzaman, M., Malek, A. B. M. A., Islam, M. M., Pandey, A. K., Rahim, N. A. (2016). Global advancement of cooling technologies for PV systems: a review. Solar Energy, 137, 25-45.

[7] Kandeal, A. W., Thakur, A. K., Elkadeem, M. R., Elmorshedy, M. F., Ullah, Z., Sathyamurthy, R., Sharshir, S. W. (2020). Photovoltaics performance improvement using different cooling methodologies: A State-of-Art Review. Journal of Cleaner Production, 122772.

[8] Piotrowski, L. J., Simões, M. G., Farret, F. A. (2020). Feasibility of water-cooled photovoltaic panels under the efficiency and durability aspects. Solar Energy, 207: 103-109.

[9] Ma, T., Li, Z., Zhao, J. (2019). Photovoltaic panel integrated with phase change materials (PV-PCM): technology overview and materials selection. Renewable and Sustainable Energy Reviews, 116, 109406.

[10] Thaib, R., Rizal, S., Mahlia, T. M. I., Pambudi, N. A. (2018). Experimental analysis of using beeswax as phase change materials for limiting temperature rise in building integrated photovoltaics. Case studies in thermal engineering, 12, 223-227.

[11] Huld, T., Amillo, A. M. G. (2015). Estimating PV Module Performance over Large Geographical Regions: The Role of Irradiance, Air Temperature, Wind Speed and Solar Spectrum, Energies, 8: 51595181.

[12] Ali, M., Iqbal, M. H., Sheikh, N. A., Ali, H. M., Shehryar Manzoor, M., Khan, M. M., Tamrin, K. F. (2017). Performance investigation of air velocity effects on pv modules under controlled conditions. International Journal of Photoenergy, 2017.

[13] Schwingshackl, C. (2013). Wind effect on PV module temperature: analysis of different techniques for an accurate estimation, Energy Procedia, 40: 77-86.

[14] Dubey, S., Sarvaiya, J. N., Seshadri, B. (2013). Temperature dependent photovoltaic (PV) efficiency and its effect on PV production in the 
world-a review. Energy Procedia, 33: 311-321.

[15] Chakraborty, S., et al. (2017). Mathematical method to find best suited PV technology for different climatic zones of India, International Journal of Energy and Environmental Engineering. 8: 153-166.

[16] Jiang, Y., Lu, L. (2016). Experimentally investigating the effect of temperature differences in the particle deposition process on solar photovoltaic (PV) modules, Sustainability, 8: 1091-1100.

[17] Performance ratio (2020, October 15) Retrieved from http://files. sma.de/dl/7680/Perfratio-TI-en-11.pdf

[18] Jansson, E., Elfving, G. (2017). Supervisor: Joakim Widén, Modelling extensive solar power production in urban and rural areas, Faculty of Science and Technology, Uppsala University.

[19] Yaka, E. et al. (2014). Rectified Solar Energy Potential Atlas of Southeastern Anatolia Region. Solar TR 2014, Solar Conference \& Exhibition proceeding, 371-375. İmir, Turkey.

[20] Global Horizontal Irradiance (2020, October 15) Retrieved from http://www.solar-med-atlas.org/solarmed-atlas/map.ht$\mathrm{m} \# \mathrm{p}=37.822802,36.386719 \& \mathrm{t}=\mathrm{ghi}$

[21] Map, Global Horizontal Irradiance (2020, October 15) Retrieved from http://www.solar-med-atlas.org/solarmed-atlas/map.ht$m \# p=37.822802,36.386719 \& t=g h i$

[22] Panasonic Solar, HIT (2020, October 15) Retrieved from https://str. panasonic.com/panel/upload/panasonic-gunes-panelleri.pdf

[23] First Solar Series $4^{\mathrm{mm}}$ (2020, October 15) Retrieved from http://fortuneenergy.net/content/sunmodule-plus-mono-5-busbar-datasheet. pdf http://www.firstsolar.com/-/media/First-Solar/Technical-Documents/Series-4-Datasheets/Series-4V2-Datasheet.ashx

[24] Sunmodule Plus, SW 290-310 (2020, October 15) Retrieved from Mono http://fortuneenergy.net/content/sunmodule-plus-mono-5-busbar-datasheet.pdf

[25] Yingli Solar YGE 60 Cell Seris 2 (2020, October 15) Retrieved from http://www.yinglisolar.com/static/assets/uploads/products/downloads/DS_YGE60CELL\%20\%20SERIES\%202\%20-29b_35mm_EN_ EN_20200407_V04.pdf

[26] Kamuyu, W. C. L., Lim, J. R., Won, C. S., Ahn, H. K. (2018). Prediction Model of Photovoltaic Module Temperature for Power Performance of Floating PVs, Energies, 11, 447.

[27] Jakhrani, A.Q. et al. (2011). Comparison of Solar Photovoltaic Module Temperature Models, World Applied Sciences Journal 14 (Special Issue of Food and Environment), 01-08.

[28] Ross, R. G. (1980). Flat-plate photovoltaic array design optimization, 14th IEEE Photovoltaic Specialists Conference, San Diego, CA, 1126-1132. 